Uludag Univ. J. Fac. Vet. Med.

34 (2015), 1,2: 1-7

\title{
Effects on Negative Energy Balance of Tannin in Dairy Cattle
}

\author{
Sezgin ŞENTÜRK ${ }^{1} \quad$ Hüseyin CIHAN ${ }^{1} \quad$ Sevim KASAP $^{1}$ \\ Zafer MECITOĞLU ${ }^{1} \quad$ Mutlu TEMIZZEL $^{1}$
}

Geliş Tarihi: 06-08-2015

Kabul Tarihi: 25-08-2015

\begin{abstract}
Tannins are polyphenolic compounds. Tannins are chemically divided into two main groups as hydrolysable tannins and condensed tannins. Tannins are used in ruminants in order to prevent ruminal tympani and the formation of high methane gas.

In the present study, it was aimed to determine the effects of tannin on of negative energy balance metabolism in dairy cattle.

Animals, after the physical examination, were divided into 2 groups as study (test group $n=10$ ) and control group $(\mathrm{n}=10)$. Herbal extract (Quebracho Colorado) of tannin (Unitan Saica Inc., Argentina) which is appropriate for animal use, was applied 90 gr per animal daily for 6 weeks (each 3 weeks in pre and postpartum period) to animals in study group. While no any tannin or other additive was given to the animals in control group. Faeces, blood and milk (only after parturition on days 7, 14 and 21) samples were collected from both group on $21^{\text {st }}$ day before parturition, during parturition and $7^{\text {th }}, 14^{\text {th }}$, and $21^{\text {st }}$ day from parturition. Beta hydroxybutyrate (BHB), albumin, calcium, phosphorus, total protein, BUN, GGT, cholesterol and triglycerides from blood samples and milk urea nitrogen (MUN) levels from milk samples were evaluated. Difference between the groups for BUN, MUN, calcium, phosphorus, triglycerides, albumin, total protein and GGT was not detected. However, a decline was detected for BHB levels during parturition, $7^{\text {th }}, 14^{\text {th }}$ (not statistically significant) and $21^{\text {st }}$ (statistically significant) days after parturition in the study group compared to the control group.

As a result; in animals, as detected lower BHB levels in animals applied tannin in study group compared to the control group, tannin can be used for the protection against negative energy balance.
\end{abstract}

Key Words: Tannin, negative energy balance, BHB, Cow.

\section{Süt Sığırlarında Tanenin Negatif Enerji Dengesi Üzerine Etkisi}

Özet: Tanenler polifenolik bileşiklerdir. Tanenler kimyasal açıdan, hidroliz olabilen tanenler ve kondanse tanenler olmak üzere iki ana gruba ayrılırlar. Tanenler ruminal timpani ve yüksek metan gazı oluşumunu engellemek amacı ile ruminantlarda kullanılmaktadır.

Sunulan çalışmada tanen maddesinin, süt sığırlarında negatif enerji dengesi metabolizması üzerine etkisini ortaya konulması amaçlanmıştır.

Hayvanlar, genel sağlık kontrolü yapıldıktan sonra, çalışma (test grubu $n=10)$ ve kontrol grubu ( $\mathrm{n}=10)$ olmak üzere 2 gruba ayrıldı. Çalışma grubuna doğum öncesi ve sonrası 3 hafta olmak üzere 6 hafta boyunca hayvan başına 90 gr hayvansal kullanıma uygun bitkisel öz kapsayan (Quebracho Colorado) tanen (Unitan Saica Inc., Arjantin) ilavesi yapılırken, kontrol grubuna tanen veya başka bir katkı ilavesi yapılmadı. Her iki grubu oluşturan hayvanlardan doğum öncesi 21 gün, doğum anı ve doğum sonrası 7., 14. ve 21. günlerde dışkı, kan ve do-

1 Department of Internal Medicine, Faculty of Veterinary Medicine, Uludag University, 165059, Bursa, Turkey, sezsen@uludag.edu.tr 
ğum sonrası haftalarda süt örnekleri alındı. Kan örneklerinden Betahidroksi butirat (BHB), albümin, kalsiyum, fosfor, total protein, BUN, GGT, kolesterol, trigliserid, süt örneklerinden; Süt üre nitrojen (MUN), düzeyleri değerlendirildi. Gruplar arasında BUN, MUN, kalsiyum, fosfor, trigliserid, albumin, total protein ve GGT değerlerinde fark bulunmadı. Bununla birlikte, çalışma grubundaki BHB düzeylerinde kontrol grubuna göre doğum anı, doğum sonrası 7. ve 14. günde istatistiksel düzeyde olmayan ama 21. günde istatistiksel düzeyde saptanan bir düşme belirlenmiştir.

Sonuç olarak; tanen uygulanan gruptaki hayvanlarda özellikle BHB düzeyinin kontrol grubundaki hayvanlara göre düşük değerde bulunması, tanenin negatif enerji dengesine karşı korumada kullanılabileceğini gösterebilir.

Anahtar Kelimeler: Tanen, negatif enerji dengesi, BHB, İnek.

\section{Introduction}

The rapidly rising energy requirement of the recently calved cows coincides with the time when dry mater intake is reduced. In order to sustain high levels of milk production; high yielding dairy cows in that period mobilize fat from body stores which results as elevated concentration of circulating ketone bodies in early lactation. When carbohydrate levels are limited, keton bodies are used by peripheral tissues as source for energy. However, as the levels of circulating keton bodies increse and sustains at elevated levels, a state which is known as ketosis occurs. Subclinical ketosis of dairy cattle is a condition characterized with presence of excess levels of circulating ketone bodies in absence of clinical signs of ketosis. Betahydroxybutiric acid (BHBA) is used for determination of ketotic status of dairy cows as it is the most stable keton body.

The main economic impact of subclinical ketosis is related with decreased milk yield ${ }^{2}$ and increase in the average calving interval ${ }^{15}$. However it is also well documented that incidence of perirarturient diseases such as displacement of abomasum ${ }^{9}$, metritis ${ }^{6-8}$ and mastitis $^{16,29}$ is higher in cows with elevated BHBA levels.

In recent years, a significant increase in our country's dairy farms has occurred. With this increase, the incidence of metabolic diseases is also increasing. Specifically, primary clinic ketosis and sub clinical ketosis that occurs as a result of negative energy balance and yield losses associated with this problem is the most important moment of our country.

Tannins are plant metabolites which are many biological effects. Tannins can be beneficial or dangerous, depending on the compound's structure, and on the dose for ruminants. Especially, low amounts of tannic acid has antimutagenic, anticarcinogenic and antioxidant effects $^{19,23}$. Tannis are considered to be antinut- ritional factors that form indigestible complexes with protein, polysaccharides, and minerals. ${ }^{27}$. The tannins have been divided into two groups as the condensed and the hydrolysable. Tannins has proved its efficiency by reducing the formation of ruminal methane gas to minumum ${ }^{4}$. Hence, tannins have the anti-bloating effect. Tannins due to specified properties are used in the ruminant nutrition.

The present study aimed to investigate the effects on protein metabolism and negative energy balance of the added tannin (MGM-S ${ }^{\circledR}$, UNITAN SAICA Inc., Argentina) to ration.

\section{Materials and Methods}

Holstein dairy cows $(\mathrm{n}=20)$ in their second and third lactation with an expected calving date within the next seven days were selected for the study. All cows were from the same herd and yield group, and the management and feeding conditions were same for all.

Cows were housed in pre- and post partum group pens, each maintained at 10 cows. Tannin (MGM-S ${ }^{8}$, UNITAN SAICA Inc., Argentina), suitable for animal use including herbal extracts (Quebracho Colorado), was given 90 grams per animal.to animals in test group (group I) during week 6 (3 weeks prior to calving, calving after 3 weeks). However, the tanin was not administered to control group (group II).

Blood samples were collected by jugular venipuncture from each cow at 7 days before expected calving date (cattle that calved more than two days early or late were excluded from the study and new ones were included), on the calving day and at 7, 14 and 21 days after calving.

All blood samples were taken in the morning, approximately 6 hours after the morning feed. At the time of each sample collection, all cows were clinically examined. Animals with 
disease such as metritis, mastitis, hypocalcemia, clinical and subclinical ketosis, lameness pneumonia and enteritis that might affect the biochemical parameters were excluded of the study.

Blood samples were obtained by coccygeal vessels into $10 \mathrm{~mL}$ evacuated tubes containing clot activator and gel for serum separation (Becton Dickinson and Company, Franklin Lakes, NJ) (Becton Dickinson and Company, Franklin Lakes, NJ), days 7. Before calving and during weeks 1,2 and 3 post calving. . Serum samples were separated off by centrifugation for 15 minutes at $1000 \mathrm{~g}$ (for BHB testing within $1 / 2 \mathrm{~h}$ of collection. hemolyzed samples were excluded to study. Serum samples were stored at $-20{ }^{\circ} \mathrm{C}$ until analysed. Samples were centrifuged again after thawing before the assay.

From serum samples; albumin, calcium, phosphorus, total protein, BUN, GGT, cholesterol, triglycerides levels were evaluated by an accredited laboratory. Samples for Beta hydroxybutyrate (BHB) were analyzed by manufacturer's recommended procedure and $\beta$ - hydroxybutyrate meter (STAT- Site ${ }^{\circledR} \mathrm{M} \beta-\mathrm{HB}$, Stanbio Laboratory, An EKF Diagnostic Company, Texas, USA). Using Stanbio STAT- Site ${ }^{\circledR} \mathrm{M} \beta$-HB test strips.

To analyze blood glucose, FreeStyle Optium Blood Glucose Test Strip (Abbott, İstanbul, TURKEY) was used. The blood samples were taken from the coccygeal vessels. Blood samples taken from the animals, directly on the strip for the glucose measurement was instilled Blood samples immediately upon receipt, with the Blood Glucose Meter (Optium Xceed Blood Glucose Meter, Abbott Inc, İstanbul, Turkey) was measured quickly without waiting based on the manufacturer's recommendations. Results were recorded.

Milk samples were taken average $50 \mathrm{~mL}$ at 10 and 20 days from all animals after calving. Samples were sent to the laboratory immediately cold chains. During those days, average milk yields at the groups were determined.

At 7.14 and 21 days after birth from all the animals, BHB levels in milk samples were measured with rapid test strips (BHB milk ${ }^{\circledR}$, Healt Matete, DFI Co., LTD, 388-25, GomoRo, Republic of Korea).

Feacal samples were collected at 7 days before calving, at 7. 14., and 21 days after calving from all the animals. The lenght of the cellulose particles and the density of undigested grain particles were evaluated. Later, the data obtained were scored, as shown in Table-1.
Table 1: Scores of stool samples

Tablo 1: Dışkı örneklerinin skorlandırılması

\begin{tabular}{|lc|}
\hline \multicolumn{1}{|c|}{ Stool samples } & score \\
\hline Porridge-like consistency and forms a dome-shaped pile & 1 \\
Large proportions of undigested grain or long forage & 2 \\
particles (pieces greater than $1.2 \mathrm{~cm}$ ) & \\
$\begin{array}{l}\text { The presence of excessive amounts of mucus, large } \\
\text { proportions of undigested grain or long forage particles } \\
\text { (pieces greater than } 1.2 \mathrm{~cm} \text { ), diarhea }\end{array}$ & 3 \\
$\begin{array}{ll}\text { Manure that appears foamy or bubbly, The presence of } \\
\text { excessive amounts of mucus, large proportions of undi- } \\
\text { gested grain or long forage particles (pieces greater than }\end{array}$ & 4 \\
$1.2 \mathrm{~cm}$ ), diarhea & \\
\hline
\end{tabular}

Values are presented as mean \pm standard error of the mean (SEM). For statistical evaluations, the SPSS program package release 10.01 (SPSS for Windows, Release 10.01, Standard version, Copyright ${ }^{\circledR}$ SPSS. Inc., 1989-1999) was used. Analysis of variance was performed using the General Linear Model procedure and Repeated Measures of SPSS. Differences were considered to be significant if $\mathrm{P}<0.05$.

\section{Results}

Pre- and post-treatment laboratary data of cows of both groups are presented in Table 2, 3, 4 and 5.

Serum calcium concentrations in both groups decreased according to calving time. Although this was not at statistical level, this reduction was determined to be underway at seventh day after calving in control group. In contrast, it was observed that the calcium levels increased in the study group after calving. In comparison with before calving, phosphorus levels shown a steady increase in the test group after calving. However, this result was not statistically significant. In control group, according to period before calving, phosphorus level statistically decreased during calving. This decline continued on the seventh day after birth.

In the assessment of triglyceride levels, although it was low at all the time of test group according to control group, there was no significant differences between the two groupsç According to weeks before and after calving, it was showed that serum glucose values were high during partrution in both group $(\mathrm{p}<0.05)$. The difference was not detected between the groups at other weeks. 
Tablo-2: Evaluation of Blood Biochemical Results

Tablo-2: Serum biyokimyasal parametrelerin değerlendirilmesi

\begin{tabular}{|c|c|c|c|c|c|c|}
\hline \multirow{2}{*}{ 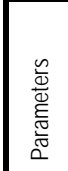 } & \multirow[b]{2}{*}{ Groups } & \multicolumn{5}{|c|}{ weeks } \\
\hline & & $\begin{array}{c}-1 \\
(m e a n \pm S E)\end{array}$ & $\begin{array}{c}0 \\
\text { (Calving) } \\
\text { (mean } \pm S E)\end{array}$ & $\begin{array}{c}1 \\
\text { (mean } \pm S E)\end{array}$ & $\begin{array}{c}2 \\
\text { (mean } \pm S E)\end{array}$ & $\begin{array}{c}3 \\
\text { (mean } \pm \\
\text { SE) }\end{array}$ \\
\hline \multirow{2}{*}{\multicolumn{2}{|c|}{ 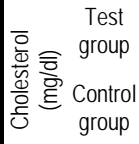 }} & $96.2 \pm 9.4^{\mathrm{bcA}}$ & $79.1 \pm 6.3^{a}$ & $91.4 \pm 8.9 \mathrm{ac}$ & $121.1 \pm 3.5^{b c}$ & $134.5 \pm 12.1^{b^{\star}}$ \\
\hline & & $134.8 \pm 9.6^{\mathrm{dbeB}}$ & $93.8 \pm 4,7^{\mathrm{a}}$ & $115.6 \pm 11.2^{\mathrm{ae}}$ & $148.5 \pm 12.2^{\mathrm{cbd}}$ & d $167.0 \pm 8,9 b *$ \\
\hline \multirow{2}{*}{\multicolumn{2}{|c|}{ 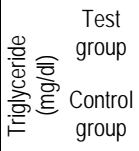 }} & $23 \pm 1.8^{a}$ & $8.7 \pm 0.8^{\mathrm{db}}$ & $16.2 \pm 2.1^{e}$ & $9.0 \pm 0.8^{\mathrm{cb}}$ & $7.4 \pm 0.9^{b^{*}}$ \\
\hline & & $24.7 \pm 2.9^{a}$ & $24.5 \pm 2.4^{\mathrm{ab}}$ & $17.7 \pm 3.1^{\mathrm{ab}}$ & $13.7 \pm 3.0^{c}$ & $9.8 \pm 1.3^{c^{*}}$ \\
\hline \multirow{2}{*}{ ๖ 흥 } & $\begin{array}{c}\text { Test } \\
\text { group }\end{array}$ & $14.5 \pm 10.6$ & $14.8 \pm 1.1$ & $12.7 \pm 0.8$ & $12.6 \pm 0.4$ & $12.4 \pm 0.4^{\mathrm{A}}$ \\
\hline & $\begin{array}{l}\text { Control } \\
\text { group }\end{array}$ & $13.1 \pm 0.6$ & $12.5 \pm 0.8$ & $14.0 \pm 0.6$ & $11.4 \pm 0.6$ & $10.6 \pm 0.8^{B}$ \\
\hline \multirow{2}{*}{\multicolumn{2}{|c|}{ 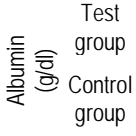 }} & $3.6 \pm 0.06^{a}$ & $3.4 \pm 0.08^{\mathrm{ab}}$ & $3.2 \pm 0.11^{b}$ & $3.2 \pm 0.11^{b}$ & $3.2 \pm 0.09^{b}$ \\
\hline & & $3.6 \pm 0.05$ & $3.6 \pm 0.1$ & $3.4 \pm 0.1$ & $3.4 \pm 0.0$ & $3.4 \pm 0.1$ \\
\hline \multirow{2}{*}{ 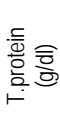 } & $\begin{array}{l}\text { Test } \\
\text { group }\end{array}$ & $7.1 \pm 0.2^{b}$ & $6.4 \pm 0.2^{\mathrm{a}}$ & $6.5 \pm 0.2^{\mathrm{ca}}$ & $7.5 \pm 0.2^{b}$ & $7.5 \pm 0.1^{\mathrm{b}^{*}}$ \\
\hline & $\begin{array}{l}\text { Control } \\
\text { group }\end{array}$ & $6.8 \pm 0.1^{\mathrm{a}}$ & $6.3 \pm 0.3^{\mathrm{a}}$ & $6.6 \pm 0.2^{\mathrm{a}}$ & $7.2 \pm 0.2^{\mathrm{ab}}$ & $7.8 \pm 0.2^{\mathrm{b}^{\star}}$ \\
\hline \multirow{2}{*}{ 烏. } & $\begin{array}{l}\text { Test } \\
\text { group }\end{array}$ & $21.5 \pm 2.1$ & $23.4 \pm 1.6$ & $19.6 \pm 1.2^{\mathrm{a}}$ & $25.3 \pm 2.1^{\mathrm{bA}}$ & $24.2 \pm 1.7$ \\
\hline & $\begin{array}{l}\text { Control } \\
\text { group }\end{array}$ & $17.5 \pm 0.9^{a}$ & $19.5 \pm 2.4$ & $17.3 \pm 1.8$ & $19.8 \pm 1.0^{\mathrm{B}}$ & $22.5 \pm 1.8^{b}$ \\
\hline \multirow{2}{*}{ 部 } & $\begin{array}{l}\text { Test } \\
\text { group }\end{array}$ & $8.5 \pm 0.1$ & $8.2 \pm 0.2^{\mathrm{a}}$ & $8.9 \pm 0.2^{b}$ & $9.0 \pm 0.1^{b}$ & $9.0 \pm 0.1^{b}$ \\
\hline & $\begin{array}{l}\text { Control } \\
\text { group }\end{array}$ & $8.9 \pm 0.2$ & $8.5 \pm 0.3$ & $8.3 \pm 0.3$ & $8.9 \pm 0.2$ & $9.2 \pm 0.1$ \\
\hline \multirow{2}{*}{ 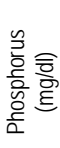 } & $\begin{array}{l}\text { Test } \\
\text { group }\end{array}$ & $5.1 \pm 0.4$ & $5.6 \pm 0.3$ & $5.7 \pm 0.3$ & $5.7 \pm 0.2$ & $5.7 \pm 0.3$ \\
\hline & $\begin{array}{l}\text { Control } \\
\text { group }\end{array}$ & $6.4 \pm 0.2^{\mathrm{a}}$ & $4.7 \pm 0.5^{b}$ & $4.9 \pm 0.5^{b}$ & $5.5 \pm 0.3^{a b}$ & $5.1 \pm 0.2^{\mathrm{ab}}$ \\
\hline \multirow{2}{*}{ 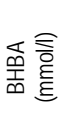 } & $\begin{array}{c}\text { Test } \\
\text { group }\end{array}$ & $1,02 \pm 0,1^{a}$ & $0.77 \pm 0,1^{\mathrm{ab}}$ & $0.95 \pm 0,11^{a}$ & $0.64 \pm 0,11^{\text {ba }}$ & $0.58 \pm 0,1^{b A^{*}}$ \\
\hline & $\begin{array}{l}\text { Control } \\
\text { group }\end{array}$ & $1.04 \pm 0.05$ & $0.80 \pm 0.06$ & $0.96 \pm 0.1$ & $0.72 \pm 0.1$ & $0.95 \pm 0.1^{B}$ \\
\hline \multirow{2}{*}{$\begin{array}{l}\text { № } \\
\text { 흘 } \\
\text { 홍 }\end{array}$} & $\begin{array}{c}\text { Test } \\
\text { gruop }\end{array}$ & $55.1 \pm 2.1^{\mathrm{a}}$ & $66.2 \pm 2.3^{b}$ & $53.5 \pm 1.3^{a}$ & $54.4 \pm 1.5^{a}$ & $51.0 \pm 1.7^{a}$ \\
\hline & $\begin{array}{l}\text { Control } \\
\text { group }\end{array}$ & $53.2 \pm 1.9 a$ & $73 \pm 2.4^{b}$ & $52.1 \pm 2.1^{a}$ & $50.1 \pm 2.1^{a}$ & $51.7 \pm 2.6^{a}$ \\
\hline
\end{tabular}

Data are expressed as means $\pm \mathrm{SEM} . * \mathrm{P}<0.05$;

a, b, c, d, e: Differences between the values involving different letters on the same row are found to be statistically significant.

A, B: significant difference between control and test groups' measurements at the same times.

Table-3: Comparison of MUN values between groups and within groups

Tablo-3: MUN seviyelerinin gruplar ve gruplar içerisinde karşılaştırılması

\begin{tabular}{|cccc|}
\hline Parameter & Grups & $\begin{array}{c}\text { 10th days after calving } \\
\text { MUN (mg/dl) } \\
(\text { Mean } \pm \text { SE) }\end{array}$ & $\begin{array}{c}\text { 20th days after calving } \\
\text { MUN (mg/dl) } \\
(\text { mean } \pm \text { SE) }\end{array}$ \\
\hline MUN $^{*}$ & Test & $12.1 \pm 0.5$ & $11.4 \pm 0.5$ \\
$(\mathrm{mg} / \mathrm{dl})$ & Control & $12.3 \pm 0.6$ & $12.2 \pm 0.9$ \\
\hline
\end{tabular}

*Not significant between groups and within groups
Table-4: Quantity of the average milk between groups and within groups

Tablo-4: Gruplar ve grupiçerisndeki süt verimlerinin ortalaması

\begin{tabular}{|cccc|}
\hline Parameter & Grups & $\begin{array}{c}\text { 10th. days } \\
\text { after calving } \\
\text { Mean } \pm \text { SE }\end{array}$ & $\begin{array}{c}\text { 20th. days after } \\
\text { calving } \\
\text { Mean } \pm \text { SE }\end{array}$ \\
\hline $\begin{array}{c}\text { The average } \\
\text { milk yield* } \\
\text { (Liter) }\end{array}$ & Test & $29.1 \pm 2.07$ & $34.0 \pm 2.66$ \\
\hline
\end{tabular}

*Not significant between groups and within groups

Table -5: Scores of Stool Samples

Tablo-5: Dıșkı örneklerinin skorlandırılması

\begin{tabular}{|ccccc|}
\hline Parameter Groups & $\begin{array}{c}\text { 7. days } \\
\text { before } \\
\text { calving } \\
\text { Mean } \pm \text { SE }\end{array}$ & $\begin{array}{c}\text { 10. days after } \\
\text { calving } \\
\text { Mean } \pm \text { SE }\end{array}$ & $\begin{array}{c}\text { 20. days after } \\
\text { calving } \\
\text { (mean } \pm S E)\end{array}$ \\
\hline Stool & Test & $1 \pm 0^{\mathrm{a}}$ & $1.81 \pm 0.2^{\mathrm{b}}$ & $1.5 \pm 0.1^{\mathrm{bA}}$ \\
Score & control & $1 \pm 0^{\mathrm{a}}$ & $2.2 \pm 0.2^{\mathrm{b}}$ & $2.1 \pm 0.2^{\mathrm{bB}}$ \\
\hline
\end{tabular}

Data are expressed as means \pm SEM. $* \mathrm{P}<0.05$;

$\mathrm{a}, \mathrm{b}, \mathrm{c}, \mathrm{d}$, e: Differences between the values involving different letters on the same row are found to be statistically significant.

A, B: significant difference between control and test groups' measurements at the same times.

Except for serum total protein values, the purpose of evaluation of protein metabolism, was determined no significant difference between the groups in levels of serum albumin, BUN and MUN. According to the data obtained from this study, we cannot mention of a positive or negative effect on protein metabolism of tanin.

According to the score of stool, the structure of animal feces in the study group were significantly better than the control group. In particular, fecal score were significantly lower the test group than control group on $20^{\text {th }}$ day after calving.

In evaluation of Beta hydroxybutyrate (BHB), the most important diagnostic parameter of the negative energy balance, have been identified as important points. In comparison with the control group, BHB in test group significantly decreased at twenty-first day after calving $(p<0.05)$. In addition, BHB in the test group compared to the control group was dropped sharply in calving time, the seventh and $21^{\text {th }}$ days after birth, but there were no significant differences between controls and tests.

In line with these results, while clinical ketosis in an animal $(\mathrm{n}=1)$ and clinical hypocal- 
cemia in an animal $(n=1)$ occured in the first 3 weeks after birth in the control group, animals in the study group did not encounter any metabolic problem.

Although it is high in tannin-treated animals, compared to the control group, between groups and within groups, there was not any statistical significance in average milk yield (Table-3).

\section{Discussion}

At the onset of lactation, even towards the end of pregnancy period, energy consumption of dairy cows is increased. If this energy is not compensated, it is inevitable occurrence of ketosis $^{12,14,24}$. Ketosis is a metabolic disorder that primarily occurs sub clinical and clinical. Clinical and subclinical ketosis are both characterized by reduced milk yield, imparied reproduction efficiency, and increased secondary diseases such as metritis, mastitis, abomasal displacement ${ }^{6,10,18,30,31,33}$. Therefore, both clinical and subclinical ketosis causes significant economic losses. So, determined of incidence of clinical and subclinical ketosis in dairy cows are important. according to the results of the incidence of clinical and subclinical ketosis, more accurate methods of protection can be created. This is one of the main objectives of the present study.

Beta hydroxybutyrate (BHB) is the most important diagnostic parameter of the negative energy balance ${ }^{25,28,32}$. The optimum BHB level for clinical ketosis has been greater than 1.0 $\mathrm{mmol} / \mathrm{l}$ serum $\mathrm{BHB}^{26}$. Some dairy cows can have high keton bodies without abvious clinical signs $^{1,10,28}$. Although BHB blood level is $>1.2$ $\mathrm{mmol} / \mathrm{l}$, perhaps the only reflection is a reduction in milk yield. These cows are termed as subclinical ketosis ${ }^{32}$.

Inpresent study, in comparison with the control group, BHB in test group significantly decreased at twenty-first day after calving $(\mathrm{p}<0.05)$. In addition, BHB in the test group compared to the control group was dropped sharply in calving time, the seventh and 21th days after birth. Tannins reduce degradation of ruminal protein ${ }^{13,20}$. This effects on protein of tannins is associated to their ability to form hydrogen bond that are stable at rumenpH. Tannin-protein complexes dissociate in the abomasum, $\mathrm{pH} 2 \cdot 5-3 \cdot 0^{20,22}$. Thus, a part of the amino acidssuch as lysine and methionine may be passes into small intestine without degradation in the rumen. However, some authors ${ }^{17,21}$ reported that tannin-protein complex might be reform in intestinal $\mathrm{pH}$ (about 5.5) and tannins might also be able to inhibit the digestive enzyme in intestinal. As a result, they inform that digestion of intestinal might be impaired. Some researchers are not participating in this opinion. Blytt et all, $1988^{5}$ indicate that bile salts prevent the binding of tannins to digestive enzymes such as trypsin and amylase. Inaddition, Waghorn, G. (1996) ${ }^{34}$ emphasizes that ruminants can benefit from dietary CT when the increases in protein flow from the rumen exceed the reduction in the absorption of aminoacids from the intestine. Inaccordance of all these statements, according to control group, present in lower concentrations of BHB in the test group might be explained by the greater availability of intestinal amino acids such as methionine and lysine that are the most important amino acids playing a role in synthesis of glucose in ruminants.

Giving a high amount of tannins can reduce dry matter intake. Also the high amounts of tannin may adversely affect the benefit from feed $^{2,3,11}$. In present study, there were no Negative effect on voluntary food intake when given $90 \mathrm{~g}$ of tannin per animal. In addition, cccording to the score of stool, the structure of animal feces in the study group were significantly better than the control group. This can be shown that increasing the benefit from feed of the tanin at the doses used.

According to HT, there are very few reports on the toxic effect of $\mathrm{CT}^{11}$. Overall, the findings of toxicity are characterised by aneroxia, depresion, ruminal atony, gastroenteritis, hepatic and renal failure. In the present study, none of the toxic effects mentioned in the tannin-treated animals did not occur.

In conclusion, these findings show that chebracho tannin, administered to cows 3 weeks before and after parturition, had antiketogenic effects by decreasing blood BHBA, suggesting that tannin may be a valuable tool for protection against the negative energy balance in dairy cattle. Hovewer, to determine the effect on negative energy balance of tannins is a need to further study. 


\section{Referances}

1. Andersson L. 1988. Sub-clinical ketosis in dairy cows. Veterinary Clinics of North America-Food Animal Practice. 4:233 - 251.

2. BARRY T.N., DUNCAN S.J., 1984. The role of condensed tannins in the nutritional value of Lotus pedunculatus for sheep. 1. Voluntary intake. Brit J Nutr 51, 485-491.

3. BARRY T.N., McNABB W.C., 1999. The implications of condensed tannins on the nutritive value of temperate forages fed to ruminants. Brit $\mathrm{J}$ Nutr 81, 263-272.

4. Bhatta R., Saravan M., Baruah L., Prasad C.S:: Effects of graded levels of tannin-containing tropical tree leaves on in vitro rumen fermentation, total protozoa and methane production. J Appl Microbiol. 2015 Mar;118(3):557-64

5. BLYTT H.J., GUSCAR T.K., BUTLER L.G., 1988. Antinutritional effects and ecological significance of dietary condensed tannins may not be due to binding and inhibiting digestive enzymes. J Chem Ecol 14, 1455-1465.

6. Dohoo, I.R. and S.W. Martin. 1984a. Disease, production and culling in Holstein-Friesian cows IV. Effects of disease on production. Prev. Vet. Med. 2:755.

7. Dohoo, I.R., and S.W. Martin. 1984b. Subclinical ketosis: Prevalence and associations with production and disease. Can J Comp Med 48: 1-5.

8. Dubuc, J., .T. F. Duffield, K. E. Leslie, J. S. Walton, and S. J. LeBlanc. 2010. Risk factors for postpartum uterine diseases in dairy cows. J. Dairy Sci. 93:5764 - 5771.

9. Duffield, T. F., K. E. Leslie, D. Sandals, K. Lissemore, B. W. McBride, J. H. Lumsden, P. Dick, and R. Bagg. 1999. Effect of a monensin controlled-release capsule on cow health and reproductive performance. J. Dairy Sci. 82: 2377

10. Duffield, T. F., K.D. Lissemore, B. W. McBride, and K. E. Leslie. 2009. Impact on hyperketonemia in early lactation dairy cows on health and production. J. Dairy Sci. 92: 571 - 580.

11. Frutos, P., Hervás, G., Giráldez, F.J., Mantecón, A.R., 2004. Review. Tannins and ruminant nutrition. Spanish Journal of Agricultural Research 2(2), 191-202.

12. Goff, J.P., Horst, R.L., 1997. Physiological changes at parturition and their relationship to metabolic disorders. J Dairy Sci 80:1260-1268.

13. Hagerman, A.E., Robbins, C.T., Weerasurıya, Y., Wilson, T.C., Mcarthur, C., 1992. Tannin chemistry in relation to digestion. J Range Manage 45, 57-62.

14. Herdt, T.H., Emery R.S., 1992. Therapy of diseases of ruminant intermediary metabolism. Vet. Clin. North Am. Food Anim. Pract. 8:91-106.
15. Kauppinen, K., 1983. Correlation of whole blood concentrations of acetoacetate, 8hydroxybutyrate, glucose and milk yield in dairy cows as studied under field conditions. Acta Vet Scand 1983; 24: 349-361.

16. Kremer, W.D.J., C. Burvenich, E.N. Noordhuizen-Stassen, F.J. Grommers, Y.H. Schukken, R. Heeringa, and A. Brand. 1993. Severity of experimental Escherichia coli mastitis in ketonemic and non-ketonemic dairy cows. J. Dairy Sci. 76:3428.

17. Kumar, R., Singh, M., 1984. Tannins: their adverse role in ruminant nutrition. J Agr Food Chem 32, 447-453.

18. LeBlanc, S. 2010. Monitoring metabolic health of dairy cattle in the transition period. J. Reprod. Dev. 56:S29 - S35

19. Lopes, G.K., Schulman, H.M., Hermes-Lima, M.,1999. Polyphenol tannic acid inhibits hydroxyl radical formation from Fenton reaction by complexing ferrous ions. Biochim Biophys Acta., 18;1472(1-2):142-52.

20. Mangan, J.L.: Nutritional Effects of Tannins in Animal Feeds. Nutrition Research Reviews,209231, 1988

21. Mcnabb, W.C., Peters, J.S., Foo, L.Y., Waghorn, G.C., Jackson, S.J., 1998. Effect of condensed tannins prepared from several forages on the in vitro precipitation of ribulose-1,5-bisphospathe carboxilase (rubisco) protein and its digestion by trypsin (EC 2.4.21.4) and chymotrypsin (EC 2.4.21.1). J Sci Food Agric 77, 201-212

22. Mueller-Harvey, I., Mcallan, A.B., 1992. Tannins. Their biochemistry and nutritional properties. In: Advances in plant cell biochemistry and biotechnology, Vol. 1 (Morrison I.M., ed.). JAI Press Ltd., London (UK), pp. 151-217

23. Nam, S., Smith, D.M., Dou, Q.P., 2001. Tannic acid potently inhibits tumor cell proteasome activity, increases p27 and Bax expression, and induces G1 arrest and apoptosis. Cancer Epidemiol Biomarkers Prev. 10(10):1083-8.

24. Nielsen, N. I., K. L. Ingvartsen. 2004. Propylene glycol for dairy cows A review of the metabolism of propylene glycol and its effects on physiological parameters, feed intake, milk production and risk of ketosis. Animal Feed Science and Technology. 115:191 - 213.

25. Oetzel, G. R. 2004. Monitoring and testing dairy herds for metabolic disease. Vet. Clin. North Am. Food Anim. Pract. 20:651 - 674.

26. Ospina, P.A., Nydam, D.V., Stokol, T., Overton, T.R., 2010. Evaluation of nonesterified fatty acids and B-hydroxybutyrate in transition dairy cattle in the northeastern United States: Critical thresholds for prediction of clinical diseases. J. Dairy Sci. 93:546 - 554. 
27. Pastuszewska, B., Kowalczyk, J., Ochtabińska, A., 2000. Dietary carbohydrates affect caecal fermentation and modify nitrogen excretion patterns in rats. II. Studies with diets differing in protein quality. Arch Tierernahr. 53(4):335-52.

28. Roberts, T., N. Chapinal, S. J. LeBlanc, D. F. Kelton, J. Dubuc, and T. F. Duffield. 2012. Metabolic parameters in transition cows as indicators for early-lactation culling risk. J. Dairy Sci. 95:3057 - 3063.

29. Schukken, H., 2000. Hyperketonemia and the impairment of udder defense: A review. Vet. Res. $31: 397-412$

30. Seifi, H.A., LeBlanc, S.J., Leslie, K.E., Duffield, T.F., 2011. Metabolic predictors of post-partum disease and culling risk in dairy cattle. Vet. J. 188:216 - 220 .
31. Senturk, S., Mecitoglu, Z., Temizel, E.M., Cihan, H., Kasap, S., Demir, G., 2010. Clinical and biochemical evaluation of cows occuring severe weight loss after calving. Uludag Univ J Fac Vet Med, 29, 43-49.

32. Sentürk, S., 2013. Sığırlarda Hangi Klinik Bulgularda Hangi Laboratuar Parametrelerine Bakılma11? F. Özsan Matbaacilık, Bursa, s; 210-231

33. Suthar, V.S., Canelas-Rapos J., Deniz, A. Heuwieser, W., 2013. Prevalence of subclinical ketosis and relationships with postpartum diseases in European dairy cows. J Dairy Sci. 96(5):292538.

34. Waghorn, G., 1996. Condensed tannins and nutrient absorption from the small intestine. Proc of the 1996 Canadian Society of Animal Science Annual Meeting, Lethbridge, Canada (Rode L.M., ed.). pp. 175-194. 
